\title{
JUURNAL_RU
}

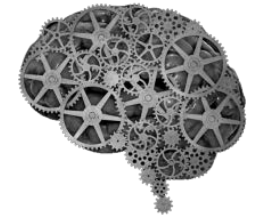

COMPANY GROUP "INTELLEKT"

\author{
Минаева А.И. \\ Московский государственный университет имени О.Е. Кутафина (МГЮА) \\ Москва, Россия
}

doi: 10.18411/lj2016-3-70

\section{Право публичного образования на репутацию и ее защиту}

Обеспечение полноценной защиты чести, достоинства и деловой репутации субъектов гражданского права является одной из составляющей построения правового государства. Право на защиту чести и достоинства воспитывает в людях уважение друг к другу и к себе, а также является проявлением уважения государством прав и законных интересов личности. Действительно, сложившееся законодательство в достаточной мере регулирует данный правовой институт, однако оставляет совсем без должного, как кажется, внимания право публичных образований на репутацию и ее защиту.

Об актуальности затронутой данной статьей проблемы свидетельствует отсутствие соответствующего законодательного механизма, однозначной правоприменительной практики, а также существующие в науке дискуссии.

Анализ ст. 152 ГК РФ позволяет сделать вывод о том, что законодатель признает право на защиту чести, достоинства и деловой репутации только за гражданином и юридическим лицом, то есть выводит публичные образования из круга субъектов, имеющих возможность защищать право на указанные нематериальные блага. Согласно п. 1 ст. 124 ГК РФ Российская Федерация, её субъекты, а также городские, сельские поселения и другие муниципальные образования выступают в отношениях, регулируемых гражданским законодательством, на равных началах с иными участниками этих отношений гражданами и юридическими лицами. Согласно п. 2 данной статьи к таким 
субъектам применяются нормы, определяющие участие юридических лиц в гражданских правоотношениях, если иное не вытекает из закона или особенностей данных субъектов (для краткости и удобства возможно использование термина «публичное образование»).

Если всё же допустить возможность защиты публичным образованием своей чести, достоинства и деловой репутации, встает вопрос: уместно ли относить данные категории к такому субъекту права? Ни законодатель, ни правоприменитель не дают им определения. Однако понимание этих категорий можно встретить в науке гражданского права, так, А. Л. Анисимов под честью понимает общественную оценку личности, определенную меру духовных, социальных качеств гражданина, под достоинством - самооценку собственных качеств, способностей, мировоззрения, своего поведения, общественного значения. А деловую репутацию, например, М. Н. Малеина определяет как набор качеств и оценок, с которыми их носитель ассоциируется в глазах своих контрагентов, клиентов, потребителей и персонифицируется среди других профессионалов в этой области деятельности. Такая позиция касательно определения понятий «честь» и «достоинство» и «деловая репутация» в целом разделяется многими учеными и активных дискуссий не вызывает.

Очевидно, что ни честь, ни достоинство не могут в полной мере характеризовать публичное образование, уже по той причине, что несут в себе отражение свойств именно человеческой личности. Категория деловой репутации может быть применима к публичному образованию, однако она отражает только одну составляющую его деятельности, а именно хозяйственноэкономическую. В науке можно встретить позицию, в частности, она представлена А. Е. Кипичевым, согласно которой государственные и муниципальные образования являются субъектами права на деловую репутацию при осуществлении ими предпринимательской деятельности, в иных случаях их репутация приравнивается к деловой, поскольку является однородным явлением. Данная позиция отражает подход, согласно которому мнение о 
публичном образовании сводится к осуществляемой им хозяйственной деятельности, однако это представляется неверным, поскольку в рамках деятельности публичного образования также происходит решение ряда других вопросов и проблем. Об этом свидетельствует, в частности, ст. 14 Федерального закона от 6 октября 2003 года № 131-Ф3 «Об общих принципах организации местного самоуправления в Российской Федерации», определяющая, что к ведению городского, сельского поселения относятся, помимо прочего, создание условий для развития местного традиционного народного художественного творчества, участие в сохранении, возрождении и развитии народных художественных промыслов, создание условий для реализации мер, направленных на укрепление межнационального и межконфессионального согласия и так далее.

В этой связи представляется разумным согласиться с мнением М. Н. Малеиной, отмечающей, что характеристику государства следует давать через категорию репутации, учитывая не только деловые, но и моральные качества публичного образования. В толковом словаре русского языка С. И. Ожегова можно найти такое понимание слова репутация как приобретаемой общественной оценки, общего мнения о качествах, достоинствах и недостатках кого-нибудь (чего-нибудь). Таким образом, репутация является более общим понятием, содержащим в себе представления о различных качествах субъекта. Исходя из этого, можно допустить, что публичное образование всё же имеет право на репутацию и право на ее защиту.

Действительно ли отсутствует правовой механизм по защите публичным образованием своей репутации? Из системного толкования норм ст. 124 и ст. 152 ГК РФ вытекает, что гипотетически публичное образование имеет право на защиту своей чести, достоинства как граждане и деловой репутации как юридические лица. Исходя из этого, в науке гражданского права, в частности, М. Н. Малеиной, выдвигается предложение о том, что для защиты права публичного образования на репутацию можно использовать предусмотренные в 
ст. 152 ГК РФ способы защиты в порядке аналогии закона. Представляется, что применение аналогии закона не является достаточным механизмом для защиты прав. Более того, при применении в совокупности норм ГК РФ, может возникнуть следующее противоречие: ст. 124 ГК РФ выступает как общая норма, регулирующая в целом возможность участия публичных образований в гражданском обороте, а ст. 152 ГК РФ - как специальная, закрепляющая порядок защиты нематериальных благ определенными в данной норме субъектами. Такой ученый как Д.Н. Кархалев придерживается позиции, согласно которой потерпевшими в правоотношении по поводу защиты нематериальных благ не могут выступать публичные образования, поскольку они не обладают правом на деловую репутацию. В подтверждение данной позиции можно встретить ссылку на п. 2 Постановления Пленума № 3 от 24 февраля 2005 г. «О судебной практике по делам о защите чести и достоинства граждан, а также деловой репутации граждан и юридических лиц», согласно которому, иски по делам данной категории вправе предъявлять граждане и юридические лица. Следовательно, что ни законодательство, ни правоприменительная практика действительно не предусматривают бесспорного полноценного механизма защиты публичным образованием своей репутации.

Исходя из этого, видится целесообразным внесение изменений в ст. 152 ГК РФ в виде включения нормы, согласно которой, публичное образование также будет являться субъектом права на защиту соответствующего нематериального блага либо создание дополнительной статьи ГК РФ, регулирующей право публичного образования на репутацию и ее защиту. Необходимость более точной регламентации субъектного состава объясняется, помимо прочего, тем, что на практике суды иногда приравнивают право на честь лица, действующего от имени публичного образования к праву на репутацию публичного образования. Более того, как отмечается учеными, осуществившими анализ соответствующих судебных решений, публичные должностные лица, как 
правило, отождествляют свою честь как гражданина и честь (репутацию) публичного образования.

Если допустить, что публичное образование обладает правом на репутацию и ее защиту, то какие способы могут применяться для этого? М. Н. Малеиной предлагается использовать такие способы как опровержение, опубликование своего ответа и возмещение убытков, а также ввести самостоятельный способ защиты в виде опубликования решения суда о допущенном нарушении. Представляется, что нет необходимости сужения перечня возможных способов защиты права на репутацию публичного образования, поскольку все способы, закрепленные в действующей ст. 152 ГК РФ, могут быть эффективны для такой защиты каждый по своему и достаточно сложно выделить такой способ, который ни при каких условиях не мог бы быть применим для достижения цели защиты права публичного образования на репутацию. Однако целесообразно закрепить также, что публичное образование вправе потребовать компенсацию репутационного вреда в бюджет соответствующего публично-правового субъекта.

Таким образом, в настоящее время отсутствует законодательное закрепление права публичного образования на репутацию, а, значит, отсутствуют и четко урегулированные механизмы ее защиты. Данный пробел законодательства представляется существенным, поскольку фактически лишает публичные образования права на защиту своего сложившегося культурного, социального, морально-нравственного облика, что при некоторых обстоятельствах может причинить публичному образованию ущерб. Представим себе следующую ситуацию: сельское поселение ставит перед собой цель привлечь больше граждан для проживания и работы в нем, в то же время в СМИ распространяются несоответствующие действительности, порочащие его репутацию сведения, например, о коррупции или о бездействии соответствующих органов публичного образования для создания надлежащих условий проживания. Распространение таких сведений в итоге приводит к тому, 
что шансы на достижение публичным образованием своей цели существенно снижаются. Безусловно, в таком случае публичное образование должно быть вправе прибегнуть к одному из представленных в ст. 152 ГК РФ способу защиты репутации.

Исходя из всего вышесказанного, представляется целесообразным внести соответствующие изменения в ГК РФ для преодоления существующего законодательного пробела.

\section{Литература:}

1. Анисимов А.Л. Честь, достоинство, деловая репутация под защитой закона. Норма, 2004 // СПС КонсультантПлюс: Комментарии законодательства.

2. Гражданский кодекс Российской Федерации (часть первая) от 18.12.2006 230-Ф3 // Российская газета, N 289

3. Гражданское право: учебник. Отв. Ред. В.П. Мозолин, А. И. Масляев. - М.: Юристь, 2003 с. 241

4. Кархалев Д.Н. Защита неимущественных прав // Юрист. - М.: Юрист, 2013, № 15. - С. 37-41

5. Малеина М.Н. Право государства (публичного образования) на репутацию. // Государство и право - 2013 - № 5 - с.100-104

6. О судебной практике по делам о защите чести и достоинства граждан, а также деловой репутации граждан и юридических лиц: Постановление Пленума Верховного Суда РФ от 24.02.2005 N 3 // "Российская газета", N 50, 15.03.2005

7. Электронный словарь русского языка С. И. Ожегова. [Интернет-ресурс: www. slovarozhegova.ru] 